\title{
Recovery from tragedies: Sustaining China's marine fisheries resources
}

\author{
$\underline{\text { Zhao B. }}^{\text {a }}$, X. Guo ${ }^{\mathrm{a}}$ and D. Marinova ${ }^{\mathrm{a}}$ \\ ${ }^{a}$ Curtin University Sustainability Policy (CUSP) Institute, Curtin University, Western Australia \\ Email:Baohui.Zhao@postgrad.curtin.edu.au
}

\begin{abstract}
China used to be relatively rich in marine fisheries resources but overfishing during the last three and a half decades has depleted China's coastal fish stocks. Fish farming has become an option to satisfy the ever-growing demand by Chinese consumers. This paper develops an exploratory model to understand the reasons causing fish stock depletion, including natural and human-made factors. It analyses China's marine fisheries resource management regimes and explores the trends in seafood demand and supply. The findings suggest that domestic marine fish farming, rather than import from overseas, will continue to be the major source of China's seafood supply. However, the safety of seafood from coastal fish farms associated with high levels of pollution remains a serious public concern and constrains this industry's development. In order to sustain and allow China's depleted marine resources to recover, better management methods, including traditional marine fisheries approaches, need to be introduced into the industry. The paper also develops a national sustainability strategy model for the restoration of the fisheries industry in China.
\end{abstract}

Keywords: Common Property, Common Pool Resources, Tragedy of the Commons, Demand and Supply Instrument, Traditional Fisheries Management 


\section{INTRODUCTION}

Since the late 1950s, China has made two major shifts in the management of its marine fisheries resources from central control to a market economy. While bringing changes in the composition of the stakeholders of the resources, the regimes implemented have produced different results with respective negative environmental implications. In recent years, major stakeholders of marine fisheries resources are exploring new avenues of management in order to recover from the depletion of China's marine fisheries resources.

\section{OUTCOMES OF CENTRAL CONTROL OF MARINE FISHERIES RESOURCES}

Under China's planned economy model, marine fisheries resources were a common property and the central control over them produced unintended but unexpected environmental outcomes. Numerous definitions of common property exist, many of them being concerned with a western interpretation of property issues: for example, common-pool resources in economics (Adams et al., 2003), land related definitions in planning ${ }^{1}$ or global commons for the environment (Anderson and Grewell, 2000). However, the Chinese definition of common property regarding marine fisheries resources reflects China's specific circumstances. They are described below.

\subsection{Marine fisheries resources as common property}

In 1958 China's planned economy kicked off its nation-wide 'people's commune movement' and 52,781 communes were established across the country (Article Collection Net, 2010). Each commune was composed of many villages. Every individual villager, fisher or farmer, was made to join the people's communes to become a 'people's commune member'. Fisher members went fishing in boats which belonged to the commune and handed over all the catch to the commune. Each commune member, old or young, working or not, was allocated a certain amount of fish. During that period (1958-1982), the marine fisheries resources belonged to the government and were used by the country's communes. Fishing activities were carried out through commune members.

Prior to 1982, when the communes were dissolved, the Chinese marine fisheries resources were a common property. The definition of common property as applied to China's marine fisheries resources at the time was: owned, controlled and managed by the government, of free-access to every commune, whose members carry out the same fishing activities with equal amount of fish allocated to them (slight differences by gender and age) as their wage, without individual rivalry over the amount of catch and without any management rights.

\subsection{Government control}

As a common property, there were two major stakeholders in the marine fisheries resources, namely the government and the commune. Under its full control, the government made all relevant policies regarding fishery resources. It also dispatched fishing tasks to the communes and the fish caught was to be sent rather than sold to the local state-run processing factories. As China was involved in the Cultural Revolution during most of that time, the government's duties of policy implementation, supervision and evaluation were poorly performed. Conservation and protection of fisheries resources were barely considered over those years. The communes were only permitted to use the fisheries resources. However, operating in their respective traditional fishing zones, the communes played an important role in organizing fishing activities ranging from boat building, boat repairing, fishing, distributing fish and coordinating with neighboring communes. Due to the low efficiency of governance, outdated equipment, backward technologies and poor communication, marine fishing production was considerably low compared to the number of people involved. During the 1970s, fishing activities were mostly conducted inshore or in fishing zones with waters not deeper than 80 meters (Fu et al., 2007).

However, as a result of the low efficiency of the central control of marine fisheries resources, it produced unintended but unexpected favorable environmental outcome. China's marine fisheries resources were conserved and marine ecosystems were kept at a comparatively sustainable level. Chen (2003) for example explains the situation in some of Tianjin's fishing villages. As commune members the villagers lacked eagerness to go fishing, but coastal marine resources were kept in balance. After 1988 fishing boats were distributed to the villagers and were full of enthusiasm. In about 15 years, fisheries resources off Tianjin's coast were on the verge of depletion. In the 1980s two local marine species, namely the yellow croaker and hair-tail, became extinct. During the 1990s, five more local species died out. China's fisheries resources is

\footnotetext{
${ }^{1}$ http://rgdirections.lands.nsw.gov.au/faqs/strata_scheme/common_property
} 
very rich with over 1500 species of fish and a large diversity of prawns, shells, crabs and so on. Marine fisheries catch in 1985 reached to 3.94 million tons ${ }^{2}$. There used to be abundance of fish at affordable price in the 1970s. Commune members even used fresh fish to make organic fertilizer. Casting down their 200 meter long fishnet in their village's inshore waters, fishers dragged it onshore, each time catching over 1000 $\mathrm{kg}$ of fish. By comparison, fishing in China's coastal waters today is like looking for a giant panda in a big sea ( $\mathrm{Li}$ and $\mathrm{Li}, 2010)$.

\subsection{Government control outcome}

Ostrom et al. (1999) cited a 1998 satellite image and indicated that China's Inner-Mongolian grassland degradation was caused by the central government management. This explanation is misleading. The pastures in Inner Mongolia were under central government management and well protected before the 1980s when China started its reform and allocated pasturelands to individual herding households. Most of the degradation took place after the leasing of the grassland ${ }^{3}$. Under the specific historical circumstances, China's central government management neither caused degradation of the grasslands, nor that of marine fisheries resources. On the contrary, it is privatization that has turned China's marine fisheries resources into common pool resources, leading to the tragedy of the commons (Hardin, 1968).

\section{MARKET ECONOMY BRINGS 'TRAGEDY OF THE COMMONS'}

China's economic reform and opening up turned a new page in its development. A series of flexible economic restructuring measures were implemented, including leasing farm land/grassland to peasants and herders. As for the fishing villagers, the policy was simply 'go and catch'. As long as you have a boat, you just need to pay a standard registration fee for it, and then you can go to sea and catch as much as you can, depending on your own luck and capability. Thus marine fisheries resources became common pool resources (CPRs). The term CPRs refers to any resource system regardless as to whether it involves property rights or not (Ostrom et al., 1999). In the case of China, the common pool resources in respect to marine fisheries resources were defined as: open to all fishing villagers who are given the right to fish in their villages' traditional fishing zones, catch as many fish as they can and dispose of them as they like, all at the cost of an annual registration fee for the boats they use.

\subsection{Individual fishing rights allocated to fishers}

Similar to farmland and grassland leased to peasants and herders (the land in China is still owned by the country), the government only gives fishers the right to fish. This is not a true privatization but relieved from the long-lasting central governmental control, the marine fisheries resources suddenly became accessible to all fishers who never had such an open access to these resources before. Since the government allowed the fishers to catch fish and make money for themselves, they didn't hesitate to do it. In such circumstances in the commons, each fisher will try to catch as much fish as possible. The system compelled the fishers to increase their catch without a limit, in a world where resources are limited. "Ruin is the destination toward which all men rush, each pursuing his own best interest in a society that believes in the freedom of the commons. Freedom in the commons brings ruin to all" (Hardin, 1968: 1244).

Under the new individual fishing rights regime, the government and fishers are the major stakeholders of the marine fisheries resources (Wang and Qin, 2007). This stakeholder structure accelerates the ruin of the common pool resources. Adding to the competition among fishers to maximize their catch at the lowest cost for themselves but at a huge cost for the marine resources, are the regional interest protectionism and administrative nonfeasance practiced by all tiers of government quickening the steps toward the tragedy of the commons. Marine fishing is a labor-intensive industry, employing millions of people (Yang and Cen, 2003). The local governments' chief normally has only three to six years tenure of office in one place, while any project aimed at conserving marine fisheries resources will bear fruit in a much longer period of time. In the absence of immediate rewards, protecting common resources slipped lower in the management priorities.

\subsection{Tragedy}

The tragedy of the commons was the inevitable destiny for marine fisheries resources after they became CPRs with individual fishing rights allocated to fishers. Fisheries resources in China's inshore and coastal

\footnotetext{
${ }^{2} \mathrm{http} / / /$ baike.baidu.com/view/76777.htm

${ }^{3}$ The satellite image used was from Sneath's article published in Science in 1998 (cited in Ostrom et al., 1999) when the grasslands had already been leased to individual herding households.
} 
waters are being depleting (Wang et al., 2006, Lou and Gu, 2005). For example, in 1990 the annual catch of large yellow croakers dropped to 2000 tons only from 108 thousand tons in 1974 (Ocean Protection, 2011). The output of scapharca subcrenata in Liaodong Bay reduced drastically to 8000 tons only in 1983 from 41 thousand tons in 1975 (Wang and Sun, 1984). These are examples of reduction of marine fisheries resources caused by human overuse.

Table 1 shows marine production in Shandong Province, one of the most productive marine fishery provinces of China. The fisheries column shows the rapid increase of marine fisheries catch from 1982 to 1999. During

Table 1. Marine fishery production, Shandong province (1982-2009)

\begin{tabular}{|l|c|l|l|}
\hline Year & $\begin{array}{c}\text { Marine Fisheries } \\
\text { Catch (tons) }\end{array}$ & $\begin{array}{l}\text { Offshore } \\
\text { Aquaculture } \\
\text { Output (tons) }\end{array}$ & $\begin{array}{c}\text { Offshore } \\
\text { Aquaculture (ha) }\end{array}$ \\
\hline 1982 & 530300 & 234700 & 23000 \\
\hline 1987 & 796500 & 464600 & 50000 \\
\hline 1992 & 1536900 & 1516900 & 77300 \\
\hline 1997 & 2974700 & 2384400 & 182000 \\
\hline 1998 & 3325600 & 2339700 & 190000 \\
\hline 1999 & 3325200 & 2697800 & 225000 \\
\hline 2000 & 3078400 & 2872600 & 280000 \\
\hline 2001 & 2780200 & 3050700 & 290000 \\
\hline 2002 & 2720600 & 3262100 & 293000 \\
\hline 2003 & 2680800 & 3360700 & 358400 \\
\hline 2004 & 2702130 & 3418840 & 398680 \\
\hline 2005 & 2680834 & 3580294 & 407390 \\
\hline 2006 & 2685040 & 3735008 & 420258 \\
\hline 2007 & 2451596 & 3535277 & 406170 \\
\hline 2008 & 2481256 & 3613510 & 426217 \\
\hline 2009 & 2449591 & 3814304 & 441403 \\
\hline
\end{tabular}

Source: compiled from Shandong Province Statistical Year Books.
That time political turmoil in China made it impossible for people to over-exploit the sea. Since 1982 China started to allocate fishing rights to individual fishers. Over the next 17 years this province's marine fishery catch increased six fold. Which marine fish can increase or breed at such a pace as to keep its numbers in balance?! Table 1 also shows the gradual decline in fisheries catch from 2000 to 2009 . Over ten years, marine catch reduced by about $21 \%$ despite the upgrade in fishing technologies and more powerful fishing boats. The decline in catch can be attributed to a certain degree to the tightening up of China's marine fishing policies and its fulfillment of bilateral fishing agreements with foreign countries. Despite this, the 'desertification' of China's marine resources has become a reality, driving more and more fishers onshore (Tan and $\mathrm{Du}, 2006$ ).

\section{ENVIRONMENTAL IMPLICATIONS}

\subsection{Overuse}

Common pool resources have traditionally included terrestrial and marine ecosystems that are simultaneously viewed as depleting and renewable. Characteristic for many of these resources is that use by one reduces the quality or quantity available to others, and use by others adds negative attributes to a resource (Ostrom et al., 1999). The figures in Table 1 help to analyze the environmental implications for Shandong. The rapid increase of marine fisheries catch indicates selfish and cruel overuse with adverse impacts on the marine ecosystems.

Many of China's traditional fishing boats use trawlers to fish. In addition to targeted and untargeted catch, ripe and larval fishes, a fishing trawler has direct adverse impact on the seabed which is a sophisticated complex habitat for many of visible and invisible marine creatures. Trawlers pose direct threat to the eco-functions of the seabed. With the introduction of more powerful trawler boats, the seabed ecosystems will endure further damage. During visits to fishing villages in Shandong Province, $\mathrm{Li}$ and $\mathrm{Li}$ (2010) were told by local fishers that apart from minimizing the mesh sizes, devices similar to blades of ploughs or knives were installed to their fishing nets. Anywhere such boats go, everything from the surface to the seabed will be captured ( $\mathrm{Li}$ and $\mathrm{Li}, 2010$ ).

The overuse of marine fisheries resources breaks the marine food chain, which will in turn endanger marine diversity, leading to the extinction, deduction in size and qualities and even gene recombination of fishes. As a consequence from 2000, there has been a drastic decrease of marine catch. To offset this reduction and meet the increasing demands of domestic and international markets, people resort to marine aquaculture.

\subsection{Marine aquaculture}

The significance of marine aquaculture in China's seafood supply and demand system is obvious. The aquaculture data in Table 1 demonstrate a continuing increase both in production and hectares used for aquaculture - production of marine aquaculture increased 16.25 times while the hectares used grew 19.19 times from 1982 to 2009 . With the reduction of marine catch since 2000, both aquaculture production and relevant hectares have gone upward by $32.79 \%$ and $57.64 \%$ respectively. 2001 witnessed the first taking over of oceanic fish catch by offshore aquaculture which further exceeded the former by around 156 percent in 2009.

The implication of oceanic aquaculture on the environment is severe. Firstly, the factory-style marine aquaculture creates abundant sewage which flows out into the sea, leading to pollution of the coastal 
environment and increase of nutrients in the water. Nutrients encourage the growth of blue-green algae, which threatens fish resources (including diseases to fish), ecosystem function and human health. In 2008, the green

algae bloom in the $29^{\text {th }}$ Olympiad event waters in Qingdao is just a reminder of how high the nutrients are in China's coastal waters. A lot of taxpayers' money was spent to keep the algae out of the event waters. Secondly, high-density marine aqua-ponds along China's coast endanger coastal biodiversity. Money-oriented ponds are built to feed the most beneficial species at the sacrifice of native species. Mollusks in most of Shandong's coast are on the verge of extinction as their habitats have been excavated and changed into prawn and crab ponds (Wen and Wen, 2000). As CPRs, China's marine fisheries resources have become a very wicked problem (Allen and Gould Jr., 1986). The vicious circle (see Figure 1) may not end just within China's waters. With the collapse of the country's coastal fisheries resources and surplus of fishing capacity, China's ocean-going fishing has developed rapidly since the 1990s. In 2004, deep-sea catch exceeded 1.25 million tons with Chinese fishing boats operating in the waters of over 30 foreign countries (Tan and $\mathrm{Du}, 2006$ ).

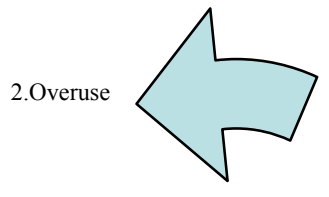

1.Demand
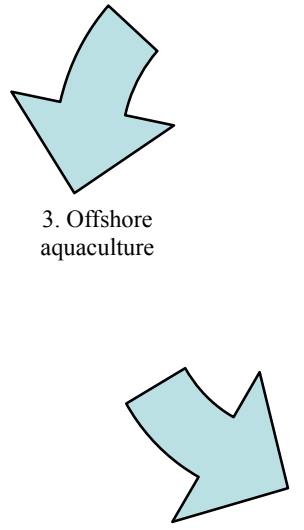

4. Marine ecosystem degradation

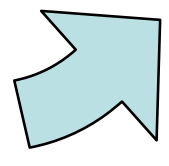

Figure 1. The wickedness China's marine fisheries resources

\subsection{Fishery demand and supply in China}

The driving force for the overuse of marine fisheries resources and the fast development of China's offshore aquaculture is the rapidly growing demand by Chinese consumers with rising incomes since the 1990s. In 2003, the annual per capita supply of marine and aquaculture products in China exceeded $36 \mathrm{~kg}$ (FAO, 2009). Table 1 also shows that total marine fishery production in Shandong Province was as high as 6.26 million tons in 2009, an increase of over $105 \%$, indicating the continued demand for seafood which is seen as "moving up the food chain efficiently" (Brown, 2005: 43). Assuming that all 6.26 million tons of seafood is consumed only by Shandong's 94.5 million residents (Shandong Province Bureau of Statistics, 2010), the per resident amount would be roughly $66 \mathrm{~kg}$, far from the $81 \mathrm{~kg}$ per person consumed in Japan in 1994 (Brown, 1995). In fact, if every Chinese person consumes $66 \mathrm{~kg}$ of seafood this year, China needs a supply of 88.4 million tons of seafood, close to the 2003 total world oceanic fish catch (around 93 million tons, Brown, 2005). If the Chinese were to consume seafood at the rate of the Japanese, there simply won't be enough as the oceanic fishery resources are being pushed to their limits. According to Tan and Du (2006), importing seafood can only be used as an instrument by policy makers to diversify the supply, rather than to influence its volume.

Rapid growth of China's offshore aquaculture provides an alternative to satisfy the ever-increasing seafood needs of the most populous China (see Figure 2). According to FAO (2009), the proportion of aquaculture production to China's total fisheries reached $64.33 \%$ in 2003 . However, industrial and agricultural pollution along China's coast undermine aquaculture production. Secondary pollution from aquaculture facilities impacts adversely on coastal waters, causing severe deterioration of the marine ecosystems. The fisheries ecological environment is endangered and some fishery areas have been seriously polluted (Ministry of Agriculture of the PRC, 2007). Malpractices and lack of advanced technologies further jeopardize the safety of aquaculture products. These may cause consumers' acceptance of the aquaculture products to decline (Smil, 2000: 178). Tan and Du (2006) recommend that while addressing the collapse of marine fisheries resources, the demand side should be taken into consideration. China's demand for seafood is massive and the growing trend for seafood consumption is irreversible. Neither the supply side nor the demand side could be easily addressed within China's context, particularly in light of the overall constraints of world marine resources conservation.

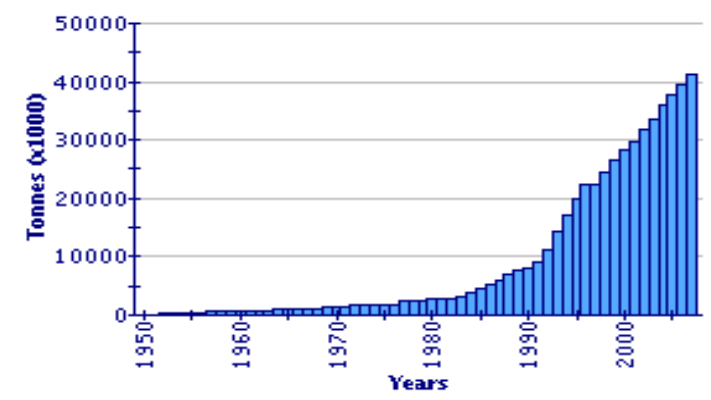

Figure 2. Aquaculture production in China

Source: Food and Agricultural Organization (FAO), (2009) 


\section{RECOMMENDATIONS AND CONCLUSION}

Suffering a lot from the destruction of the CPRs, the stakeholders of marine fisheries resources in China are exploring ways of managing them so as to recover from the tragedy of the commons. Fishers in Jiangsu, Liaoning and Shandong Provinces have set up their own associations to regulate fishing, put in place moratorium activities and conserve their common marine resources (Yang et al., 2006). In Zhejiang Province, fishery cooperatives have been established to nurture marine fisheries resources (Zhao, 2010). Fishers in Fujian Province have invested in artificial reefs to restore the fisheries ecology over the years (Ao, 2011). Explaining the cause for less degradation of Mongolia's grasslands compared to the Russian and Chinese grasslands, Ostrom (1999) writes "in this instance, Mongolia has allowed pastoralists to continue their traditional groupproperty institutions, which involve large-scale movements between seasonal pastures" (Ostrom et al., 1999: 278). "Tradition" is a very important element and plays a significant role in managing CPRs. There is a need for China to undertake effective measures to empower local fishing communities and build on their traditional knowledge and practices (Qiu, 2010).

Given the above characteristics of Chinese marine fishery resources, the following recommendations are suggested for the management of CPRs.

- Fishers operating in the same traditional fishing zones should set up their own associations to regulate fishing, conservation and stock proliferation activities in their respective zones. By contrast to China's agricultural land policies which involve a lot of uncertainty and anxiety, those zones should be granted definite permanent right of use by these associations and allow legitimate fishing zone transfers among associations, creating a sense of ownership by the members of the association.

- All associations should enter into strategic partnerships with independent marine fishery institutions for science and technology backup.

- While following government laws and regulations, all associations at the same level should take collective, united actions in matters relating to the rights and interests of the association.

Thus, an association with members who share the same values and access to modern technology should contribute to the sustainability of China's marine fishery resources. This will involve high consensus, shared values and attitudes among fishers, access to technologies by fishers, familiarity and connectedness with the traditional zones, favorable political and economic policies and low public sector efficiencies.

China's central governmental control over marine fisheries resources in the past gained unexpected positive environmental results. The so-called new socialist market economy is responsible for ruining the country's marine fisheries resources. In this instance, China's case actually has failed both of Hardin (1968)'s central control and privatization remedies.

China enjoys many successful examples of traditional and communal management of common resources. The Dujiangyan Irrigation System built over two thousand years ago is still benefiting the farmers. The pasture shifts arrangement among ethnic Mongolian pastoralists in Xinjiang is another good example. However, governing and sustaining marine fisheries resources in China is more difficult due to its wickedness, complexity and uncertainty as explained by Allen and Gould Jr. (1986). In addition, China has its own special characteristics and circumstances. In summary, ensuring a more and safer seafood supply to its people should rely more on China itself by nurturing the country's own marine fisheries resources and upgrading its aquaculture rather than on other seafood exporting nations. The stakeholders of China's marine fisheries resources are exploring new regimes so as to recover from the tragedy of the commons and this includes drawing from the wisdom of the past as well as looking towards a sustainable future.

\section{AKNOWLEDGEMENT}

The second and the third author want to acknowledge the financial support of the Australian Research Council.

\section{REFERENCES}

Adams, W.M., D. Brockington, J. Dyson, and B. Vira (2003). Managing tragedies: Understanding conflict over common pool resources, Science, 302(5652), 1915-1916.

Allen, G.M., and E.M. Gould Jr. (1986). Complexity, wickedness, and public forests. Journal of Forestry, 84(4), 20-24.

Anderson, T.L., and J.B. Grewell (2000). Property rights solutions for the global commons: Bottom-up or topdown? Duke Environmental Law \& Policy Forum, 10(2), 73-101.

Ao, R. (2011). Fujian province explores 'marine pastures'. http://www.bjagri.gov.cn/adk/pjb/detail?model=PUB 
ADKWZ_NMYH_WZXS\&do, accessed May 20, 201.

Article Collection Net (2010). Chapter 17, the organizational foundation for the great famine. http://xk.2000y.net/788423/index.asp?xAction=xReadNews\&NewsID=2890, accessed July 24, 201.

Brown, L.R. (2005). Outgrowing the earth: the food security challenge in an age of falling water tables and rising temperatures. Earthscan London. p43.

Brown, L.R. (1995). Who will feed China?, wake-up call for a small planet. W.W. Norton \& Company, New York, London. p30.

Chen, X.F. (2003). The deteriorating fishing villege. http://www.people.com.cn/GB/paper2742/11239/1015889.html, accessed May 16, 2011.

Food and Agricultural Organization (FAO) (2009). National aquaculture sector overview: China. http://www.fao.org/fishery/countrysector/naso_china/en, accessed May 20, 2010.

Ministry of Agriculture of the PRC (2007). Report on the state of the fishery eco-environment in China: summary. http://www.jsof.gov.cn/art/2008/5/22/art_37_23466.html, accessed June 23, 2011.

Fu, X.M, T.T. Song, G.L. Dai, Y.N. Wang, S.B. Lu, H.S. Guan, and C.Y. Wang (2007). Status and issues of marine fisheries resources in Shandong province and the strategies for its sustainable exploitation. Transactions of Oceanology and Limnology 2, 164-170.

Hardin, G. (1968). The tragedy of the commons, Science 162, 1243-1248.

Li, Z.B., and Y. Li (2010). Fishery resources of Qingdao City is depleting. http://news.sina.com.cn/c/2010-1220/123621674182.shtml, accessed May 19, 2011.

Lou, D., and S.Z. Gu (2005). Fishery resources, spatial distribution of fishery and its evolution in china. Chinese Journal of Agricultural Resources and Regional Planning 26(1), 27-31.

Ocean Protection (2011). Depletion of fisheries resources in China, http://mkd.lyge.cn/a78/05/30/000.htm, accessed July 25, 2011.

Ostrom, E., J. Burger, C.B. Field, R.B Norgaard, and D. Policansky (1999). Revisiting the commons: local lessons, global challenges. Science, 284, 278-282.

Qiu, W. (2010). Governing Marine Protected Areas (MPAs) in China: Towards the Repositioning of the Central State and the Empowerment of Local Communities. Doctoral thesis, UCL (University College London). http://discovery.ucl.ac.uk/643546/1/643546.pdf, accessed July 25, 2011.

Shandong Province Bureau of Statistics (2010). Annual report on fisheries production 2009. http://www.statssd.gov.cn/tjsj/nj2010/indexch.htm, accessed June 8, 2011.

Shandong Province Bureau of Statistics (2004). Fisheries production in Shandong Province (1978-2003). http://tjsj.baidu.com/pages/jxyd/28/29/f732e7354c8baed618f990641afd0e7f_0.html accessed July 22, 2011.

Smil, V. (2000). Feeding the world: A challenge for the twenty-first century. The MIT Press, Cambridge, Massachusetts London England, p178.

Tan, X.W, and Z.X. Du (2006). An analysis of China's fishery sustainability. Economic Study Reference 35, 4349.

Wen, Z.L., and Y.M. Wen (2000). Impact of aquaculture on the environment. Environment Science 1, 29-31.

Wang, M., and M. Qin (2007). A game analysis on stakeholder of the development of marine fishery. Chinese Fisheries Economics 3, 19-23.

Wang, S.B., Z. Song, and P. Li (2006). Current situation of China fishery resources and countermeasures for the sustainable development. China Fisheries Resources 1, 24-27.

Wang, Z.C., and B.L. Sun (1984). Changes of the number of scapharca subcrenata in Liaodong Bay. Fisheries Science 3, 10-14.

Yang. Z. Y., and H. Cen (2003). A positive analysis on the production function of marine fishery under the condition of market economy in China. China Fisheries Economy 5,6-8.

Yang, Z. Y., X. D. Shen, and F. H. Wu (2006). On functions of fishermen's association in the process of sustainable development of marine fisheries economy in China: a case study on fishermen's association in Laobagang town in Hai/an county. Fisheries Economy Research 4, 8-14.

Zhao, L. M. (2010). Ecological fisheries: the direction for modern fisheries. http://www.zszs.cn/slwm/2010/06 /22 /101191.htm, accessed May 21, 2011. 